\title{
RESEARCH ON THE MICROSTRUCTURE OF A Ti6Al4V-AA1050 EXPLOSIVE-WELDED BIMETALLIC JOINT
}

\author{
RAZISKAVA MIKROSTRUKTUR EKSPLOZIVNO VARJENIH \\ BIMETALNIH SPOJEV Ti6A14V-AA1050
}

\author{
Robert Kosturek $^{1}$, Marcin Wachowski ${ }^{1}$, Lucjan Śnieżek ${ }^{1}$, Adam Kruk ${ }^{2}$, Janusz Torzewski ${ }^{1}$, \\ Krzysztof Grzelak ${ }^{1}$, Janusz Mierzyński ${ }^{1}$ \\ ${ }^{1}$ Military University of Technology, Faculty of Mechanical Engineering, 2 Generala Witolda Urbanowicza Street, Warsaw, Poland \\ 2Department of Physical and Powder Metallurgy, Faculty of Metal Engineering and Industrial Computer Science, AGH University of Science \\ and Technology, al. A. Mickiewicza 30, Krakow, Poland \\ Prejem rokopisa - received: 2018-07-15; sprejem za objavo - accepted for publication: 2018-10-17
}

doi:10.17222/mit.2018.153

\begin{abstract}
Some of the most interesting materials with superior ballistic resistance are light-alloy laminated composite plates. The appropriate technology to produce these composites is the explosive-welding method. In this study, Ti6Al4V and AA1050 were successfully bonded during an explosive-welding process. The microstructure of the obtained bimetal joint was examined with scanning electron microscopy on the samples prepared using the ion-polishing method. Scanning electron microscopy allowed us to investigate the grain size in the joint area and the presence of the melted zones in the joint area, formed as a result of local mixing of both joined materials. In order to investigate the melted zones in terms of the presence of intermetallic compounds, linescans and transmission-electron-microscopy observations with SAED were performed. The obtained results allowed us to identify the intermetallic compounds, which occurred in the melted zones. The scanning-electron-microscope observations indicated a severe plastic deformation of both materials in the joint zone. An analysis of the microstructure of the joint zone with a particular emphasis on the melted zones was performed together with the tomography carried out with the focused-ion-beam scanning-electron-microscope method (FIB/SEM). The strain hardening of the joined materials was established with a microhardness analysis.

Keywords: explosive welding, Ti6Al4V, microstructure, intermetallic compounds
\end{abstract}

Nekaj najbolj zanimivih materialov z odličnimi protibalističnimi lastnostmi je izdelanih iz laminatnih kompozitnih plošč na osnovi lahkih zlitin. Primerna tehnologija za njihovo izdelavo je metoda eksplozivnega varjenja. V tej študiji so avtorji s postopkom eksplozijskega varjenja med seboj uspešno spojili zlitini Ti6A14V in AA1050. Mikrostrukturo ionsko poliranih vzorcev izdelanih bimetalnih spojev so opazovali pod vrstičnim elektronskim mikroskopom (SEM). Opazovanje pod SEM je omogočalo določitev velikosti kristalnih zrn na mestu spoja in prisotnost pretaljenih področij, ki so nastala kot rezultat lokalnega mešanja obeh materialov. S pomočjo linijskega skeniranja na presevnem elektronskem mikroskopu (TEM/SAED) so raziskovali pretaljena področja glede na nastanek intermetalnih spojin. Dobljeni rezultati so omogočili identifikacijo intermetalnih spojin, ki so nastale v pretaljenih področjih spoja. SEM posnetki kažejo, da je med eksplozijskim varjenjem prišlo do močne plastične deformacije obeh materialov na mestu spajanja. Analizo mikrostrukture v področju spoja s poudarkom na pretaljena področja so izvedli tudi s tomografijo na FIB/SEM. Z meritvami mikrotrdote na bimetalnem spoju so potrdili deformacijsko utrjevanje eksplozijsko varjenih materialov.

Ključne besede: eksplozivno varjenje, Ti6Al4V, mikrostruktura, intermetalne spojine

\section{INTRODUCTION}

Light-alloy laminated composites are some of the most promising materials for military applications due to their combination of low density and ballistic resistance. ${ }^{1-4}$ Some of the most interesting laminates in terms of the application for ballistic panels are Al-Ti alloy systems..$^{5-9}$ The appropriate technology for obtaining such laminated metal composites (LMC) is the explosive-welding method, a solid-state welding process, in which the metallic bond between the elements is formed due to a high velocity collision caused by the detonation of the explosive material. ${ }^{10-14}$ As the result of a severe plastic deformation during bonding, as well as local mixing of the joined materials, melted zones (vortexes)

*Corresponding author e-mail: robert.kosturek@wat.edu.pl can be formed. ${ }^{14,15-17}$ These areas often contain joint defects such as voids and cracks, and for this reason, their presence in the joint interface is highly undesirable. Additionally, in the case of Al-Ti, explosive-welded laminated intermetallic compounds with a Ti-Al phase may occur in the melted zones. ${ }^{14,18-21}$

\section{EXPERIMENTAL PART}

The aim of this research was to study the microstructure of explosive-welded sheets of titanium alloy Ti6A14V and aluminum alloy AA1050 with a particular emphasis on the melted zones. The chemical composition of the welded plates is presented in Table 1. As the explosive material, a mixture of ammonium-nitrate fuel oil (ANFO) was used. The scheme of the explosivewelding system is presented in Figure 1. Metallographic 


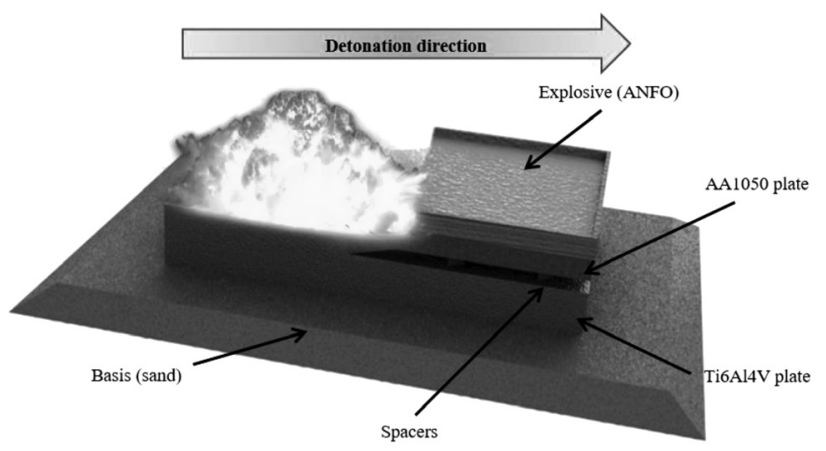

Figure 1: Scheme of the explosive-welding system

observations were carried out using samples cut from the welded sheet in the direction perpendicular to the welding direction. The microstructure of the specimens was investigated with a ZEISS scanning electron microscope equipped with energy-dispersive X-ray spectroscopy (EDS) and a back-scattered electron (BSE) detector. EDS was used to perform the mapping measurements of the chemical-composition distribution throughout the cross-sections of the samples. Observations were carried out along the cross-sections of the samples using acceleration voltages in a range of 10-16 kV. Linescans were performed at an acceleration voltage of $15 \mathrm{kV}$. Before the structural examinations, all the samples were subjected to a metallographic preparation involving ion polishing. In order to present the distribution of intermetallic precipitates in the melted zone, tomography was performed using the focused-ionbeam scanning-electron-microscope method (FIB/SEM). Additionally, the obtained joint was subjected to a microhardness analysis with a load of $100 \mathrm{~g}$ and the established microhardness distribution allowed us to estimate the strain hardening of the materials joined in the explosive-welding process.

\section{RESULTS}

The scanning electron microscopy performed on the Ti6Al4V-AA1050 explosive-welded joints revealed a flat-shaped geometry of the obtained bond. No imperfections such as cracks or voids were noticed, which indicates a defect-free structure of the joint interface. Between the joined materials, a continuous melted zone occurs with a width of about $5-10 \mu \mathrm{m}$. The photos of the joint are presented in Figure 2a.

The average grain size in the joint zone is $2.3 \pm 0.8 \mu \mathrm{m}$ for AA1050 and 3.2 $\pm 0.3 \mu \mathrm{m}$ for Ti6Al4V (Figure 2b).
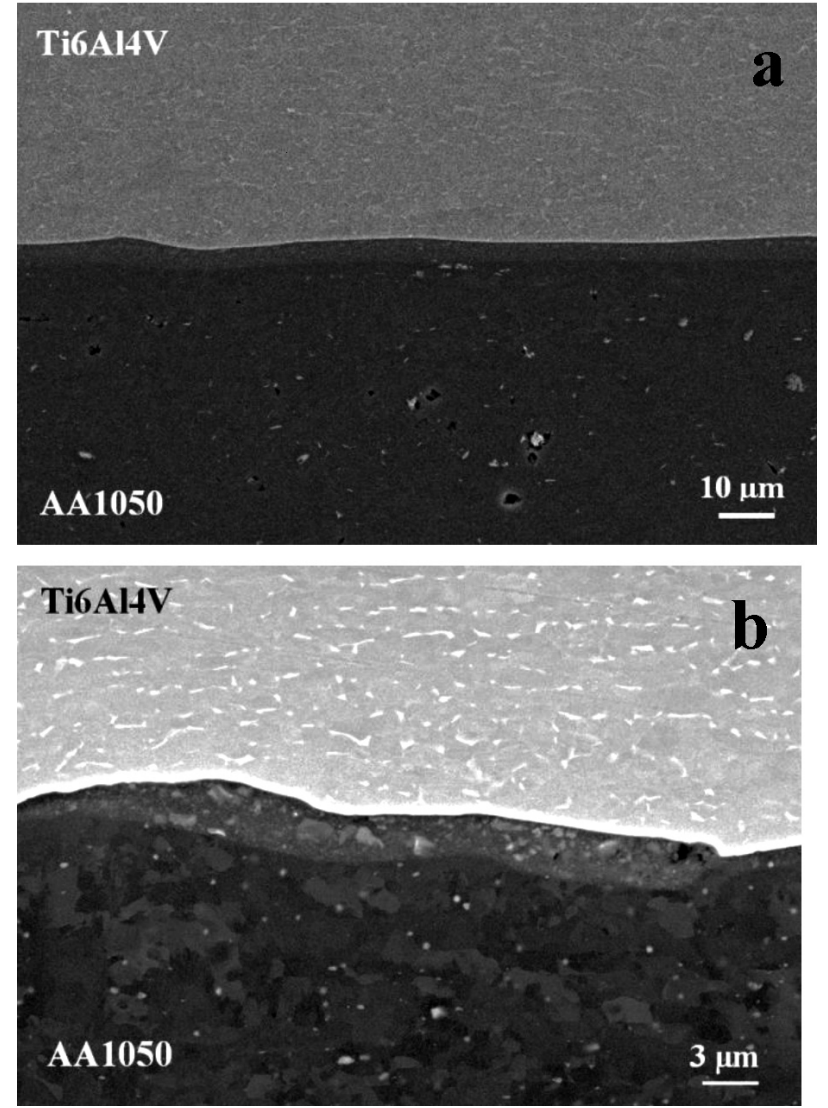

Figure 2: Scanning-electron-microscopy images of the joint interface

Directly on the joint line, there is a $4.5-\mu \mathrm{m}$ wide region of Ti6Al4V fragmented grains with a size of $1.4 \pm 0.3 \mu \mathrm{m}$ (Figure 3).

The analysis of the distribution of the main alloying elements in the joint area - titanium (Figure 4a) and aluminum (Figure 4b) - indicates that the melted zone contains a mixture of both joined materials with a predominance of aluminum. Titanium is concentrated in the precipitates occurring in the melted zone, which were subjected to further investigations.

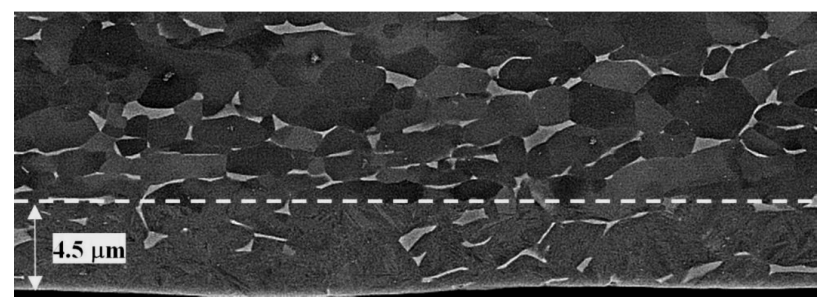

Figure 3: Scanning-electron-microscopy image of the Ti6Al4V microstructure of the joint zone

Table 1: Chemical composition of the welded plates

\begin{tabular}{|c|c|c|c|c|c|c|c|c|}
\hline & $\mathrm{Fe}(\%)$ & $\mathrm{Si}(\%)$ & $\mathrm{Zn}(\%)$ & $\mathrm{Mg}(\%)$ & $\mathrm{Ti}(\%)$ & $\mathrm{Mn}(\%)$ & $\mathrm{Cu}(\%)$ & $\mathrm{Al}(\%)$ \\
\hline \multirow{2}{*}{$\mathrm{AA} 1050$} & 0.4 & $0.25<$ & $0.07<$ & 0.18 & $0.05<$ & $0.05<$ & $0.05<$ & balance \\
\cline { 2 - 9 } & $\mathrm{O}(\%)$ & $\mathrm{V}(\%)$ & $\mathrm{Al}(\%)$ & $\mathrm{Fe}(\%)$ & $\mathrm{H}(\%)$ & $\mathrm{C}(\%)$ & $\mathrm{N}(\%)$ & $\mathrm{Ti}(\%)$ \\
\hline \multirow{2}{*}{ Ti6A14V } & $<0.20$ & 3.5 & 5.5 & $<0.30$ & $<0.0015$ & $<0.08$ & $0.05<$ & balance \\
\hline
\end{tabular}



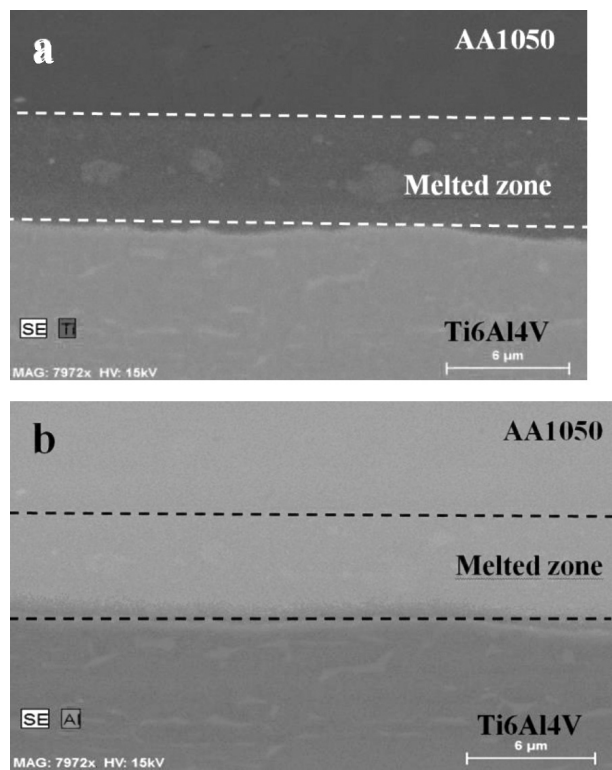

Figure 4: Distribution of alloying elements on the surface of a sample from the joint area: a) titanium and b) aluminum

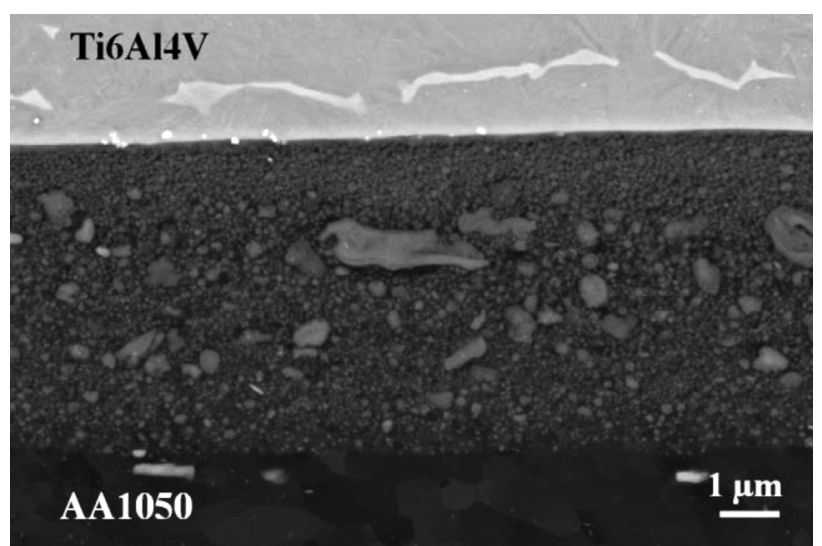

Figure 5: Scanning-electron-microscopy image of the precipitates in the melted zone

The precipitates are localized in the melted zone as an almost uniform dispersion with the average size of $0.18 \mu \mathrm{m}$. It was noticed that a fine dispersion of the precipitates occurs near the Ti6Al4V alloy layer. On the
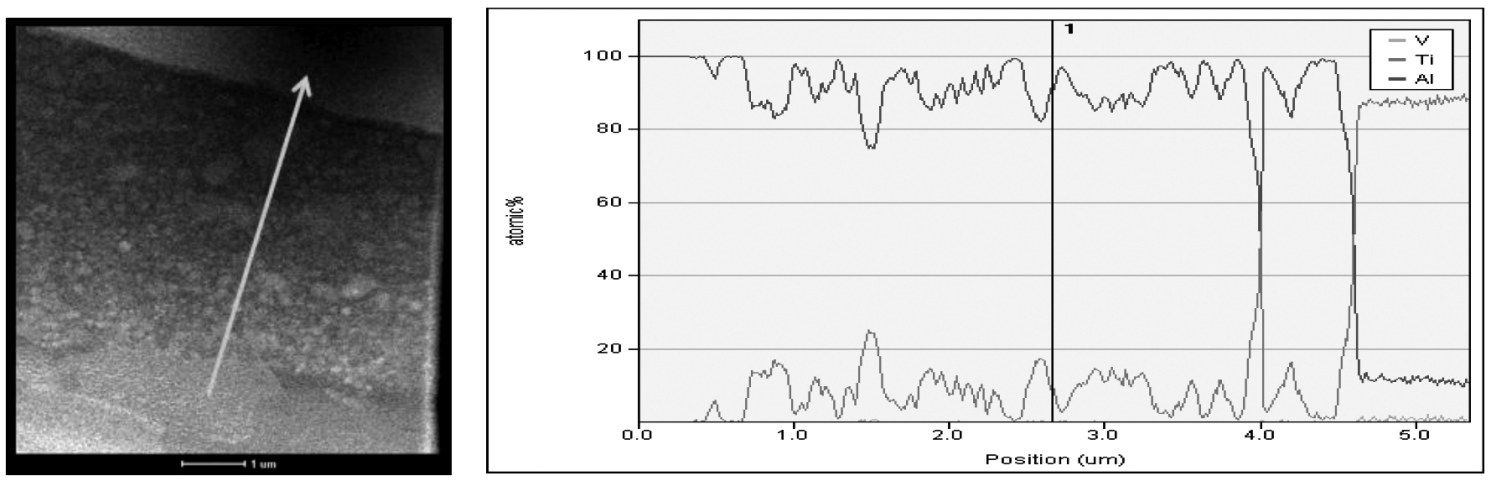

Figure 6: Linescan-analysis results for the melted zone
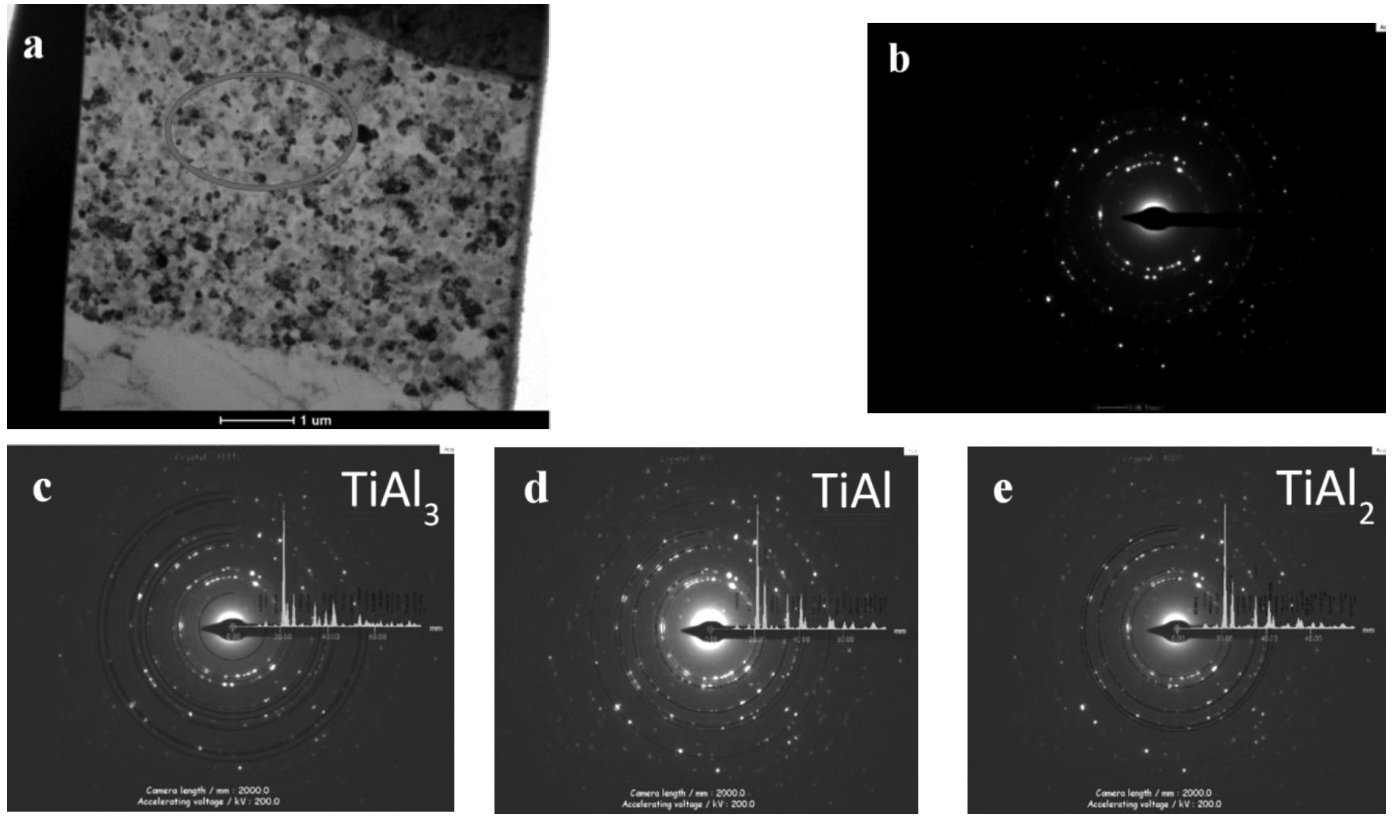

Figure 7: Transmission electron microscopy of the melted zone and the SAED analysis results for the marked area compared to the Ti-Al intermetallic patterns 



Figure 8: FIB-SEM tomography together with a 3D visualization of the precipitates

other hand, larger precipitates were found in the middle of the melted zone (Figure 5).

The results of the linescan analysis confirmed the fluctuations in the concentrion of the alloying elements in the melted zone, indicating differences between the distributions of titanium and aluminum in the precipitates and the surrounding melted zone (Figure 6).

Transmission electron microscopy (Figure 7a) and selected area diffraction (SAED) were performed in order to investigate the precipitates in the melted zone (Figure 7b). The obtained pattern was compared to the patterns of the Ti-Al intermetallic compounds. As a result, three intermetallic compounds were found in the melted zone: $\mathrm{TiAl}_{3}$ (Figure 7c), TiAl (Figure 7d) and $\mathrm{TiAl}_{2}$ (Figure 7e).

In order to present the distribution of the intermetallic precipitates in the melted zone, the FIB-SEM tomography was performed (Figure 8a) together with a $3 \mathrm{D}$ visualization (Figure $\mathbf{8 b}$ and $\mathbf{8 c}$ ).

The results of the microhardness analysis indicate a slight increase in the microhardness of the jointed materials due to explosive welding carried out at a distance of $100 \mu \mathrm{m}$ from the joint line (Figure 9). The measured microhardness of the base materials before the welding process was $350 \pm 12 \mathrm{HV} 0.1$ in the case of Ti6Al4V and $40 \pm 5$ HV0.1 in the case of AA1050. Compared to the base-material microhardness, the microhardness of AA1050 and Ti6Al4V was higher by about 15 HV0.1 and $40 \mathrm{HV} 0.1$, respectively.

\section{DISCUSSION}

The explosive-welding technology allowed us to produce a defect-free joint between the Ti6Al4V and AA1050 alloys. The joined materials were subjected to a severe plastic deformation during the welding process that resulted in a fragmentation of the grains in the joint zone. The average grain size of AA1050 in the joint zone was established as $2.3 \pm 0.8 \mu \mathrm{m}$. At the same time, the

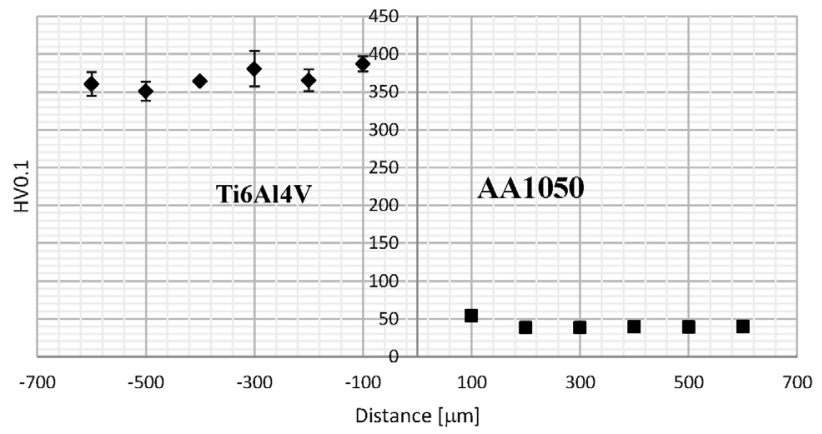

Figure 9: Results of the microhardness analysis

difference in the grain size of Ti6Al4V allowed us to specify two regions: the first one occurred at a distance of up to $4.5 \mu \mathrm{m}$ from the joint line, with the average grain size of $1.4 \pm 0.3 \mu \mathrm{m}$, and the other region exhibited the average grain size of $3.2 \pm 0.3 \mu \mathrm{m}$. The presence of a continuous melted zone in the joint with the average width of 5-10 $\mu \mathrm{m}$ was reported. The result of the distribution of alloying elements on the surface of a sample indicates that the melted zone was formed during explosive welding due to the mixing of both joined materials with a predominance of the AA1050 alloy. The concentration of aluminum in the melted zone is uniform, in contrast to titanium, which is concentrated in the precipitates occurring in this area. For the precipitates distributed in the melted zone, the average size of $0.18 \mu \mathrm{m}$ was reported. The results of FIB-SEM tomography allowed us to perform a 3D visualization of the precipitates in the analyzed melted zone. Selected area diffraction (SAED) indicates a presence of three intermetallic types: $\mathrm{TiAl}_{3}, \mathrm{TiAl}$, and $\mathrm{TiAl}_{2}$. The formation of intermetallic compounds in the melted zone was caused by local melting and mixing of the joined materials during the explosive-welding process. Plastic deformation of the welded plates caused their strain hardening, which was investigated with a microhardness analysis. The microhardness of the joined materials slightly increased at a distance of $100 \mu \mathrm{m}$ from the joint line.

\section{CONCLUSIONS}

Explosive welding of AA1050 and Ti6A14V results in a formation of the joined materials and a fragmentation of the grain structure. The continuous melted zone occurring in the joint exhibits a fine dispersion of intermetallic precipitates. An analysis of the precipitates allowed us to identify the types of intermetallic compounds as $\mathrm{TiAl}_{3}, \mathrm{TiAl}$, and $\mathrm{TiAl}_{2}$.

\section{Acknowledgment}

This work used the results of the research made within a project co-financed by the Polish Ministry of National Defense, no. PBG/13-998. This work was also 
supported by Project PBS2/A5/35/2013 funded by the National Research and Development Centre.

\section{REFERENCES}

${ }^{1}$ I. Crouch, The Science of Armour Materials, Woodhead Publishing 2016

${ }^{2}$ H. Gower, D. S. Cronin, A. Plumtree, Ballistic impact response of laminated composite panels, Inter. J. of Imp. Eng., 35 (2008), 1000-1008, doi:10.1016/j.ijimpeng.2007.07.007

${ }^{3}$ M. Übeyli, Y. Orhan, B. Ögel, On the comparison of the ballistic performance of steel and laminated composite armors, Mat. and Des., 28 (2007), 1257-1262, doi:10.1016/j.matdes.2005.12.005

${ }^{4}$ S. M. R. Khalili, R. A. Mittal, K. S. Gharibi, A study of the mechanical properties of steel/aluminium/GRP laminates, Mat. Sc. and Eng. A, 412 (2005), 137-140, doi:10.1016/j.msea.2005.08.016

${ }^{5}$ N. Thiyaneshwaran, K. Sivaprasad, B. Ravisankar, Work hardening behavior of Ti/Al-based metal intermetallic laminates, The Int. J. of Adv. Man. Tech., 93 (2017), 361-374, doi:10.1007/s00170-0169382-x

${ }^{6}$ D. Peruško, S. Petrović, M. Stojanović, M. Mitrić, M. Čizmović, M. Panjan, M. Milosavljević, Formation of intermetallics by ion implantation of multilatered $\mathrm{Al} / \mathrm{Ti}$ nano-structures, Nuc. Instr. and Meth. in Ph. Research Section B., 282 (2012), 4-7, doi:10.1016/j.nimb. 2011.08.038

${ }^{7}$ L. M. Peng, J. H. Wang, H. Li, J. H. Zhao, L. H. He, Synthesis and microstructural characterization of Ti-Al3 Ti metal-intermetallic laminate (MIL) composites, Scr. Mat., 52 (2005), 243-248, doi:10.1016/j.scriptamat.2004.09.010

${ }^{8}$ M. Ma, P. Huo, W. C. Liu, G. J. Wang, D. M. Wang, Microstructure and mechanical properties of $\mathrm{Al} / \mathrm{Ti} / \mathrm{Al}$ laminated composites prepared by roll bonding, Mat. Sc. and Eng.: A, 636 (2015), 301-310, doi:10.1016/j.msea.2015.03.086

${ }^{9}$ H. Yu, C. Lu, K. Tieu, H. Li, A. Godbole, X. Liu, C. Kong, Enhanced materials performance of $\mathrm{Al} / \mathrm{Ti} / \mathrm{Al}$ laminate sheets subjected to cryogenic roll bonding, J. of Mat. Res., 32 (2017), 3761-3768, doi:10.1557/jmr.2017.355

${ }^{10}$ T. Z. Blazynski, Explosive Welding, Forming and Compaction, Applied Science, 1983, doi:10.1007/978-94-011-9751-9

${ }^{11}$ F. Findik, Recent developments in explosive welding, Mat. and Des., 32 (2011), 1081-1093, doi:10.1016/j.matdes.2010.10.017
${ }^{12}$ R. Kosturek, M. Najwer, P. Nieslony, M. Wachowski, Effect of heat treatment on mechanical properties of Inconel 625/steel P355NH bimetal clad plate manufactured by explosive welding, Adv. in Man., (2018), 681-686, doi:10.1007/978-3-319-68619-6_65

${ }^{13}$ D. M. Fronczek, R. Chulist, Z. Szulc, J. Wojewoda-Budka, Growth kinetics of TiAl3 phase in annealed Al/Ti/Al explosively welded clads, Mat. Let., 198 (2017), 160-163, doi:10.1016/j.matlet.2017. 04.025

${ }^{14}$ D. M. Fronczek, R. Chulist, L. Litynska-Dobrzynska, G. A. Lopez, A. Wierzbicka-Miernik, N. Schell, Z. Szulc, J. Wojewoda-Budka, Microstructural and phase composition differences across the interfaces in Al/Ti/Al explosively welded clads, Metall. and Mat. Trans. A, 48 (2017), 4154-4165, doi:10.1007/s11661-017-4169-8

${ }^{15}$ G. H. S. F. L. Carvalho, I. Galvão, R. Mendes, R. Leal, A. Loureiro, Formation of intermetallic structures at the interface of steel-to-aluminium explosive welds. Mat. Ch., 142 (2018), 432-442, doi:10.1016/j.matchar.2018.06.005

${ }^{16}$ H. Paul, M. M. Miszczyk, R. Chulist, M. Prażmowski, M. Mariusz, J. Morgiel, A. Gałka, M. Faryna, F. Brisset, Microstructure and phase constitution in the bonding zone of explosively welded tantalum and stainless steel sheets, Mat. \& Des.,153 (2018), 177-189, doi:10.1016/j.matdes.2018.05.014

${ }^{17}$ A. Loureiro, R. Mendes, J. B. Ribeiro, R. Leal, I. Galvão, Effect of explosive mixture on quality of explosive welds of copper to aluminium, Mat. \& Des., 95 (2016), 256-267, doi:10.1016/ j.matdes.2016.01.116

${ }^{18}$ M. Mirjalili, M. Soltanieh, K. Matsuura, M. Ohno, On the kinetics of TiAl3 intermetallic layer formation in the titanium and aluminum diffusion couple, Intermet., 32 (2013), 297-302, doi:10.1016/ j.intermet.2012.08.017

${ }^{19}$ D. Peruško, S. Petrović, J. Kovač, Z. Stojanović, M. Panjan, M. Obradović, M. Milosavljević, Laser-induced formation of intermetallics in multilayered Al/Ti nano-structures, J. of Mat. Sci., 47 (2012), 4488-4495, doi:10.1007/s10853-012-6311-8

${ }^{20}$ B. Greenberg, M. Ivanov, M. Pushkin, A. Inozemtsev, A. Patselov, A. Tankeyev, S. Kuzmin, V. Lysak, Formation of intermetallic compounds during explosive welding, Met. and Mat. Tran. A, 47 (2016), 5461-5473, doi:10.1007/s11661-016-3729-7

${ }^{21}$ I. Bataev, D. Lazurenko, S. Tanaka, K. Hokamoto, A. Bataev, Y. Guo, A. Jorge Junior, High cooling rates and metastable phases at the interfaces of explosively welded materials, Acta Mat., 135 (2017), 277-289, doi:10.1016/j.actamat.2017.06.038 